\title{
Correction to: Global Diplomacy
}

Thierry Balzacq, Frédéric Charillon and Frédéric Ramel

\section{Correction to:}

T. Balzacq et al. (eds.), Global Diplomacy, The Sciences Po Series in International Relations and Political Economy, https://doi.org/10.1007/978-3-030-28786-3

The original version of the book was inadvertently published without the translation copyright statement. This has now been updated in the copyright page of the book.

The updated version of the book can be found at https://doi.org/10.1007/978-3-030-28786-3 